\title{
The Image Of Manahan Region
}

\author{
Ita Dwijayanti ${ }^{1}$, Andi Dwi Nugroho²
}

\author{
${ }^{1}$ Architecture Lecture, Universitas Surakarta, Surakarta \\ 2 Student of Architecture Program, Universitas Surakarta, Surakarta
}

\author{
Article History \\ Received : 15 March 2018 \\ Accepted : 15 March 2018 \\ Published : 01 October 2018
}

\begin{abstract}
Architects should have great knowledge as well as broad perspective when planning a project in a big scale (or in macro scale e.g. public buildings). The good knowledge insight is important to recognize and understand two important things: (a) Architecture of City, and also (b) Urban Design. In both fields, an understanding of the background, context, and aspects of architectural design is important to have. A city area basically can be built from a structure or mass customization of buildings that are well designed individually or entirely. Urban planning has at least three main objectives and concerned with (a) security, (b) comfort and (c) beauty (aesthetics). Manahan is considered as one of the images of the Solo because it has an epic history, infrastructure, technology, and green open spaces that are able to facilitate all circles of society both in education and tourism. The qualitative method was applied in this study with two data collection methods, that were (a) observations \& direct fields survey around Manahan Region, and (b) capturing photographs of potential buildings that support the urban area. The topical and visual analysis of architecture descriptive was also applied as analytical method upon the obtained data. The result of this analysis is a brief description that Manahan potentially provides culinary zone, educational, offices and services space, and also sport facilities equipped with good infrastructure. A statue of Soekarno (First President of Republic of Indonesia) shows the image of educated and cultured Manahan.
\end{abstract}

Keywords: Image, Manahan, Solo

\section{INTRODUCTION}

\section{Background of The Study}

Manahan Region is located in the sub-district of Banjarsari. The word "Manahan" is associated with the times when the Surakarta Palace was developed in the era of Paku Buwono III and Paku Buwono IV towards the end of the 18th century. Allegedly, the word is a play on the word panahan or archery, which is what a prominent field in the area used to be used for. Over time, the archery activity turned into equestrian activities. The traces can be identified by the existence of "horse stables" in various places

Correspondence: Ita Dwijayanti

Architecture Lecturer, Universitas Surakarta,

Surakarta

E-mail: dwijayanti2013@gmail.com in Solo city and in the Sultan's complex both in Kasunanan and Mangkunegaran. Nowadays Manahan is a village name in Surakarta and is one of 13 urban villages in the Banjarsari subdistrict. Banjarsari sub-district is the largest of the 5 sub-districts in Surakarta (Dispendukcapil Surakarta, 2017).

Figure 1. Map of Manahan Village, Banjarsari

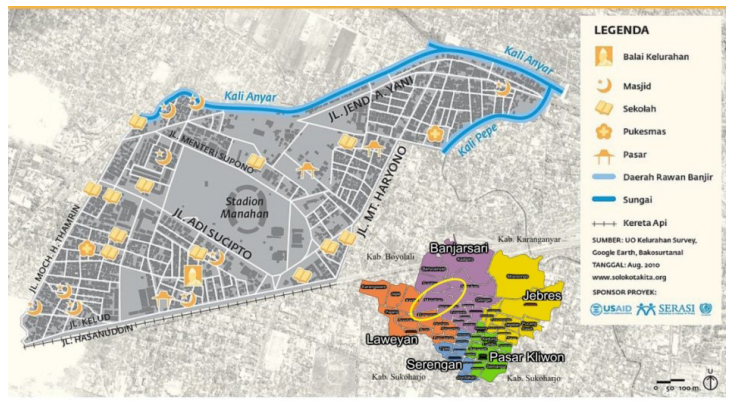

Signs of change in Manahan region could be seen in a contemporary manner in 1998 
where an international standard sports stadium was built and went by the name of "Manahan Stadium." Manahan Region was originally an archery sport venue, then changed into a racetrack, turned into a sports area, and now serves as one of the public spaces for the citizens of Solo, including a culinary spot.

\section{Problems and The Objectives of The Study}

Every city must consist of the heart, which is a center of trade, education, and identically identified with the park in it. Commonly, the center of the city can cause various public problems such as a traffic jam; therefore, the urban planning should be well designed and implemented. The space of this region must be arranged as well in order to accommodate the various activities of a complex society. The important thing to do might be in the form of physical spatial planning and functions such as land use structure, intensity of spatial use, building arrangement, circulation system and connecting lane, parking, environmental quality management, as well as infrastructure systems and environmental utilities.

The objective of this study is to introduce the image of Manahan region in view of the current times and conditions. The change of signage at a certain location in this region is one of the efforts to depict that Manahan is not only for supporting sports but also education. The construction of the current Manahan flyover has caused interesting pros and cons to be discussed.

\section{Limitations of the Study}

This study was limited in observation and data collection in fields. The observation was only focused on Manahan Region because Manahan has a football stadium which is widely used for either national or international scale, which can lead to many problems. In regard to this, the descriptions of those problems and current infrastructure conditions should be detailed clearly. (Figure 2)

\section{LITERATURE REVIEW}

\section{Physical Characteristics of an Area}

According to Trancik (1986), there are three main theories in urban design that provides system to design a good and comfortable area or city. The three theories are ground figure, linkage, and place.

\section{A. Figure Ground}

According to Trancik (1986), ground figure is the first step in understanding a region's architectural form. The analysis of this ground figure discusses the relationship between building masses (solid) and open space (void) in an urban area, to identify the shape and pattern of the city.

\section{B. Linkage}

Linkage describes the relationship of a place to another place and circulation (dynamic) in an urban space. According to Zahnd (1999: 108-129) there are three approaches to discuss urban linkage, including:

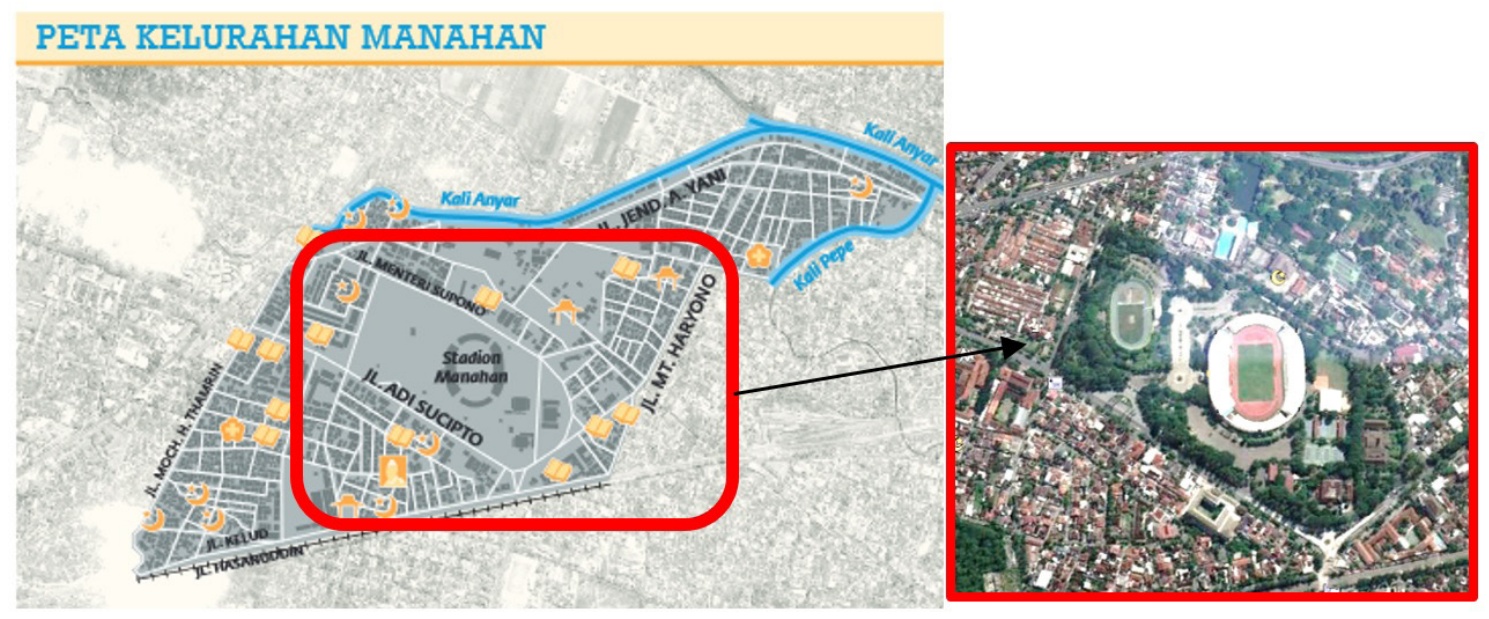


visual elements in urban areas that have two main differences, namely:

- Linkage that connects two regions neutrally.

- Linkage that connects two regions with priority in one area.

In the visual linkage there are five elements that produce a visual relationship, namely lines, corridors, axes, sides, and rhythms.

b. Structural Linkage: Forming a pattern of urban space that functions as a stabilizer and coordinator in the city environment. This linkage also has two main differences such as visual linkage and there are 3 elements, namely: connection, addition, and copy.

c. Collective Linkage: Having a special attention to the collective forms in the city, which will result in a foundation for urban design through grouping various objects. In this linkage, there are 3 elements, namely: compositional form, mega form, and group form.

\section{Place Theory}

According to the analysis of Lynch (1973) the image of the city is divided into five elements, namely:

a. Path. It is the main element in urban imagery because it is commonly used by people to move in circulation routes, including roads, main alleys, railroad, and etc.

b. Edge. This refers to the linear element that provides a barrier between a region with other regions, that may be roads, rivers, railroads, mountains, etc.

c. District (region). Areas that are formed and spread in an urban area which has a different form of activity and character than the surrounding area. The district should have clear boundaries with the surrounding area and can be seen homogeneously.

d. Node. It is an intersection in a strategic area where the direction or activity meets and can be changed towards or other activities such as traffic intersections, markets, and city roundabouts that give the impression of 'entering' and 'going out' in the same place for those who pass it.

e. Landmark. Landmarks are a prominent visual form of a city with the nature of attracting attention and helping people to recognize the city, such as mountains, tall buildings, towers, and places of worship. Landmarks usually have a special feature and become a point of interest of an area.

\section{Element of Urban Planning}

These elements below are compiled by various criteria to create the ideal urban area (Shirvani, 1985:7), including:

a. Land use

Land use is an important element in urban design because the development and improvement of the urban area will be conducted based on it. There are several things should be considered in urban planning (Shirvani, 1985:7):

- Land use permitted by government to be developed in that area

- Relations between functions that should exist in city center

- Maximum capacity of land according to each area function that has been permitted

- New scale of development

- Incentive development type that are appropriate and can be developed with certain characteristics in an area.

b. Building Form and Massing

Shirvani (1985:11) stated that building form and massing are related to physical aspects, height and appearance that are influenced by: (1) physical form, (2) height of building, (3) appearance and (4) building layout.

c. Circulation and Parking Area

The intended circulation is the circulation for vehicle, both motor and non-motor. The circulation includes achievement, magnitude, capacity and direction of circulation. As part of the circulation, parking has an influence on the city environment, which supports commercial activities in the city center and has a visual impact on the physical form and structure of the city. Factors that influence the existence of parking area include motorization, circulation, and development factors (Wicaksono, 1989:26).

d. Open Space

Open space is a non-built-up land in the city with certain use. First, open space in city is defined as a part of urban land that is not occupied by buildings 
and can only be known if part or all of the land is surrounded by fences. Furthermore, open space is defined as land with a specific use whose function or quality is seen from its contexture (Rapuano, 1964: 11). In short, open space is one of the important elements of the city in the form of non-built land which contains physical and social components.

e. Pedestrian Ways

Iswanto (2006) explained that pedestrian can be interpreted as people who walk, while way is the track or road as a media on the earth to lead people achieving the goal of walk. In this context, pedestrian is people movement from one to other place by walking. This pedestrian way is not only the part of aesthetic program in urban design but also supports the retail activities and increases vitality of the city.

f. Activity Supports

These supporting activities include all building functions and activities that support the public space of an urban area. Supporting activities not only provide pedestrian or plaza roads but also consider the main functions and application of city elements that can coerce activities, such as shopping centers, recreational parks, office centers, libraries, etc. (Shirvani, 1985: 37).

g. Signage

Signage is an element that color and describe the dynamics of urban life. Signs can be in the form of instructions that can communicate directly or indirectly. Direct communication can exhibit location, business identity and services. Indirect communication can configurate the image and character of the sign and region. Signage should be able to describe the special character of the area or building, does not cause visual disruption, and should be harmonious with building architecture and strives to be easily seen and easy to remember (Shirvani, 1985: 40-44). In today's urban life, advertisements put the city's visual space through billboards, banners and etc. This greatly affects the visualization of the city either in macro and micro.

\section{Non-physical Characteristics of an Area}

The non-physical characteristics are related to the relationship between humans and their social and culture environment that is used as a background in forming certain physical environments (Trancik, 1986).

\section{A. Activity System}

Rapoport (1977) in his book "Human Aspects of Urban Form" explained that activities arising in an area can be analyzed in the following ways:

a. Existing activities, such as shopping, traveling, eating and more.

b. A supporting place to carry out these activities, for example shopping at bazaars, walking in pedestrian ways and etc.

c. Additional activities

d. Symbolic aspects in activity. Philosophy in carrying out these activities.

Behavioral patterns of human in certain area can generate the form of that area or region.

\section{B. Socio-culture}

According to Koentjaraningrat (1996) the definition of culture is a whole system of ideas, actions, and results of human work in the framework of the society life that is used as human property by learning. Every human being has a culture, and culture is a characteristic of a place. Meanwhile, the unity of the social system of the community in built environment is called physical culture. Settlements are determined by the building environment, local natural conditions, community with value systems. This makes the urban village very closely related to the social and cultural values of its residents.

\section{Economy}

The basic function of the city is to generate enough income through the production of goods and services (Branch, 1995). Urban economics can be reviewed from three parts. The first is the economy of the government including the implementation of city government; the second is the private economy consisting of various kinds of activities organized by private companies; and the third is special economies consisting of various non-profit organizations. The underlying economy of the city is also reflected in the physical conditions of the facilities and constructions. 


\section{Literature of Manahan}

A. Perancangan Interior di Velodrome Manahan- Solo- Devy Anggoro Haftiyan (2017)

Source : digilib.isi.ac.id.

B. Media Baru \& City Branding (Studi Deskriptif kualitatif Strategi City Branding Kota Surakarta Melalui Aplikasi Solo Destrastion Berbasis Android Tahun 2015- YL.Putra (2015). Source : eprint. ums.ac.id.

\section{METHOD}

This study is a qualitative experiment. The data were obtained in this study by (a) observation and surveys around Manahan Region, and (b) capturing any photographs of potential buildings that support the construction of urban area. Meanwhile, topical and visual analysis of architecture descriptive were applied as the methods of analysis in this study. A 24hour observation and field survey had been conducted since the development of flyover is yet to begin until construction is completed.

Table 1. Elements of Figure Ground in Manahan Region

\begin{tabular}{|c|c|}
\hline Elements of Figure Ground & The area that forms figure ground \\
\hline & Regional Structure \\
\hline \multirow{7}{*}{ Linear } & - Areas along Jl. MH. Thamrin \\
\hline & - Areas along Jl. MT. Haryono \\
\hline & - Areas along Jl. A. Yani \\
\hline & - Areas along Jl. Menteri Supeno \\
\hline & - Areas along Jl. Adi Sucipto \\
\hline & - Areas along Jl. Sam Ratulangi \\
\hline & - Small street areas in residential housing around Manahan. \\
\hline \multirow[t]{2}{*}{ Grid } & $\begin{array}{l}\text { - Settlement areas in residential and residential housing around Mana- } \\
\text { han }\end{array}$ \\
\hline & Solid \\
\hline Medan Block & $\begin{array}{l}\text { - Residential area in residential and residential complexes south of } \\
\text { Manahan }\end{array}$ \\
\hline Single Block & - Manahan Stadium \\
\hline \multirow{2}{*}{ Block that defines the contents } & - Educational and office areas along Jl. Adi Sucipto \\
\hline & - Trade areas around Jl. Menteri Supeno and Jl. MT. Haryono \\
\hline
\end{tabular}

(Source: Author's Analysis, 2017)

Figure 3. Map of the Figure Ground of Manahan
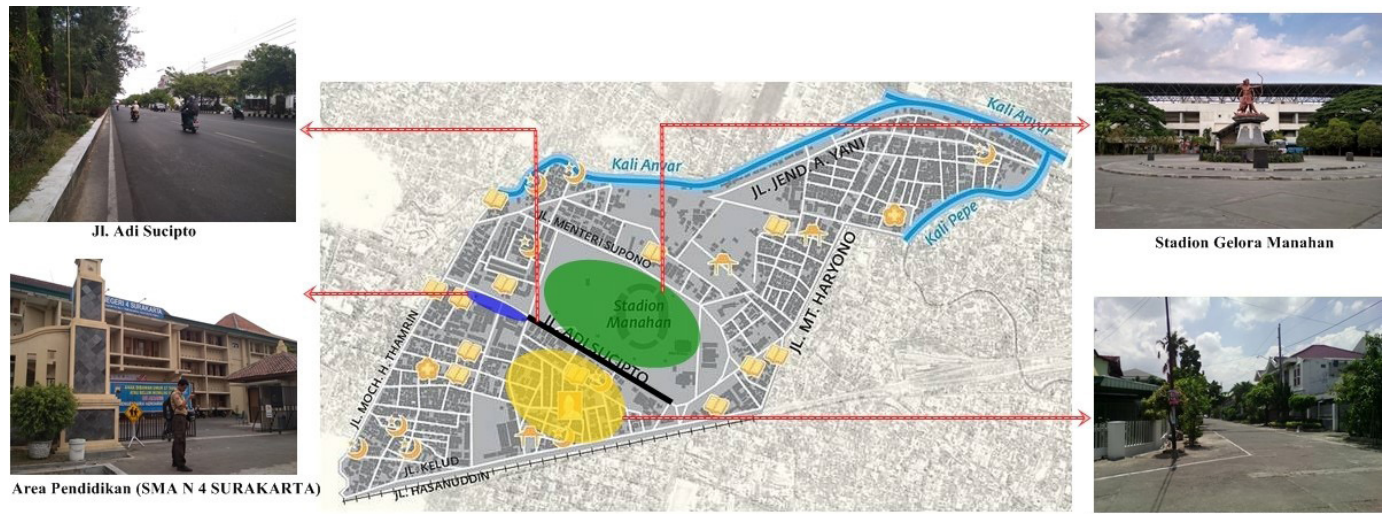

Stadion Gelora Manaha

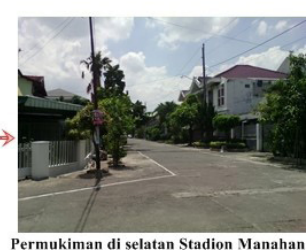


A. Analysis of Figure Ground

This is a good tool to identify a texture and urban spatial pattern also identify problems of mass/ urban space. (Table 1)

The picture (Figure 3 ) below shows the depiction of Table 1.

\section{B. Analysis of Linkage}

The analysis refers to theories on elements that connect one place to another from various aspects and confirm the relationship of the movement of an urban spatial structure. (Table 2)

The picture (Figure 4) below shows the explanation of the Table 2.

Visual linkage from the lines can be seen on highway e.g. Jl. Adi Sucipto, JI. MT. Haryono, Jl. MH Thamrin, Jl. A. Yani, and Jl. Menteri Supeno, aldo small roads in Manahan Region. The corridor element can be found in the west of Manahan Stadium, but the axis in the east of Manahan is shown by roundabout (at the end of Jl. Adi Sucipto).

Collective linkage includes group form where the buildings in Manahan Region have difference shapes and sizes based on their function.

\section{Analysis of Place}

This refers to an analysis of an area or region within some coverage elements around Manahan. The elements are as follows. (Table 3)

The picture (Figure 5) below shows the depiction of the Table 3 .

Table 2. Elements of Linkage in Manahan Region

\begin{tabular}{|c|c|}
\hline Linkage Elements & The area that form the linkage elements \\
\hline \multicolumn{2}{|r|}{ Visual } \\
\hline Line & $\begin{array}{l}\text { - Roads in residential areas around Manahan including highway such as Jl. } \\
\text { Adi Sucipto, Jl. MT. Haryono, Jl. MH. Thamrin, Jl. A. Yani, and Jl. Menteri } \\
\text { Supeno. }\end{array}$ \\
\hline Corridor & - Along Jl. Menteri Supeno (most of it is trade area) \\
\hline Axis & - J1. Adi Sucipto (traffic roundabout in the end of street) \\
\hline \multicolumn{2}{|r|}{ Structural } \\
\hline Connection & $\begin{array}{l}\text { - Sport area which provoke the appearance of active trading such as culinary } \\
\text { as well as offices and services. }\end{array}$ \\
\hline \multicolumn{2}{|r|}{ Collective } \\
\hline Groupform & - Various types of buildings with different sizes and functions \\
\hline
\end{tabular}

(Source: Author's Analysis, 2017)

Figure 4. Analysis of Visual Linkage Manahan
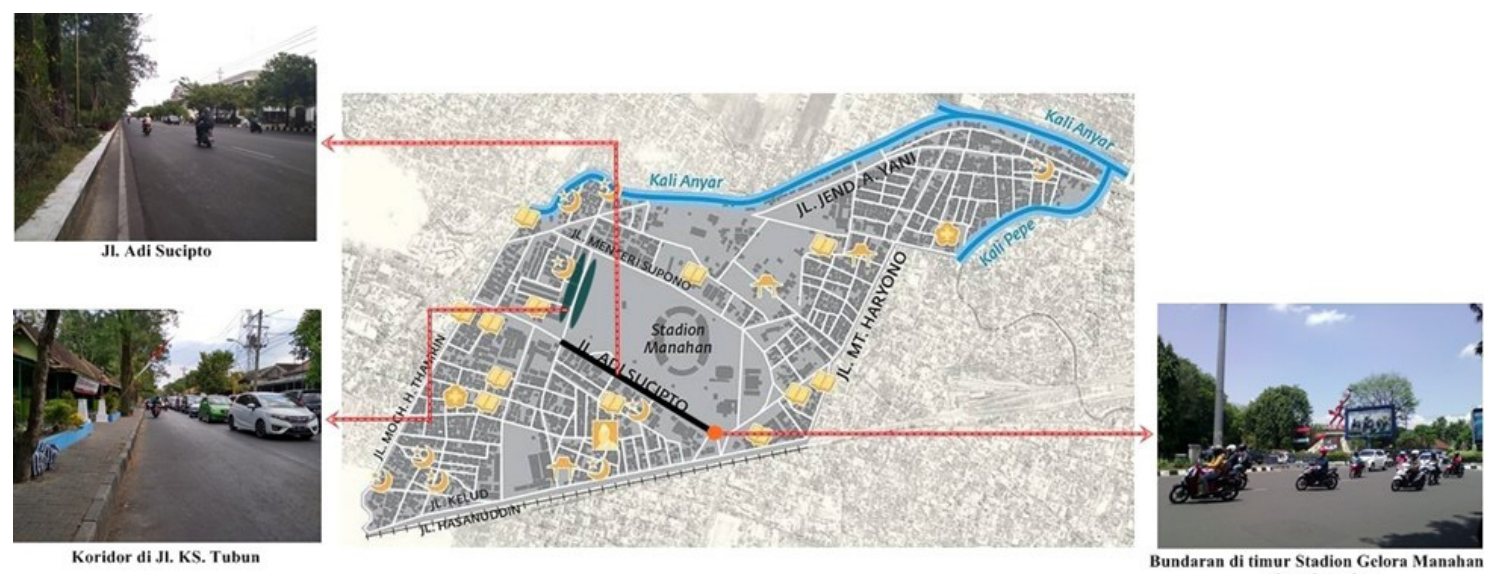

Koridor di JI. KS. Tubun

Bundaran di timur Stadion Ge 
Table 3. Elements of Place in Manahan Region

\begin{tabular}{|c|c|}
\hline $\begin{array}{c}\text { Elements of } \\
\text { Place }\end{array}$ & The Area that form elements of place \\
\hline Path & $\begin{array}{l}\text { - Jl. Adi Sucipto, J1. MT. Haryono, Jl. MH. Thamrin, Jl. A. Yani, and Jl. Menteri } \\
\text { Supeno which is the main road in the Manahan Region as a linear pattern forming. } \\
\text { - Small roads in the area of housing and settlement in Manahan Region as forming } \\
\text { grid patterns. }\end{array}$ \\
\hline Edge & $\begin{array}{l}\text { - J1. A. Yani as a roadblock with the villages in the north of Manahan. } \\
\text { - J1. Sam Ratulangi as a roadblock with the villages in the south of Manahan. }\end{array}$ \\
\hline District & $\begin{array}{l}\text { - Education area } \\
\text { - Office and Service Areas } \\
\text { - Sports and Trade Area (market, culinary) }\end{array}$ \\
\hline Node & $\begin{array}{l}\text { - A roundabout crossing in the west of Manahan Region with an archery statue. } \\
\text { - The four junction in west of Manahan stadium is a crossroad from J1 . Adi Sucipto } \\
\text { with Jl. KS. Tubun which brings the Culinary Area with Offices and Service together. }\end{array}$ \\
\hline Landmark & $\begin{array}{l}\text { - Manahan Stadium is a landmark as a sport, culinary, and public space area in } \\
\text { Banjarsari District and Solo City. } \\
\text { - Statue of Ir. Soekarno in front of the stadium area was a symbol of Manahan as an } \\
\text { educational area. }\end{array}$ \\
\hline
\end{tabular}

(Source: Author's Analysis, 2017)

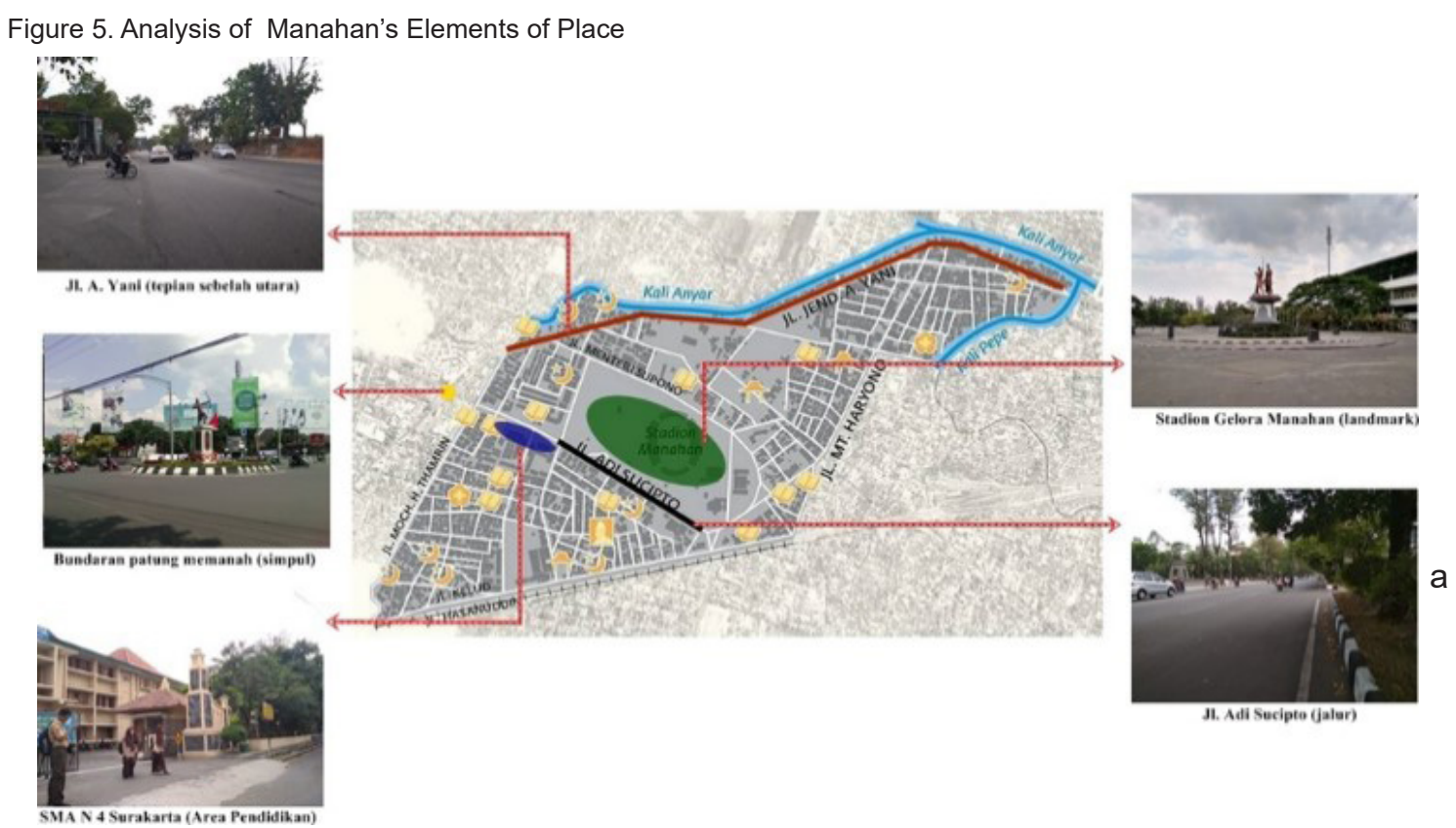

\section{Analysis of Urban Planning}

This kind of analysis is applied to determine the elements of architecture in an urban area that can influence the process of establishing Manahan sub-district. Those elements are land use, building form and massing, circulation andparking area, open space, pedestrian ways, supporting activities and signage that result in establishing a secure, comfort and beautiful area (Table 4). 
Table 4. Elements of Urban Planning in Manahan Region

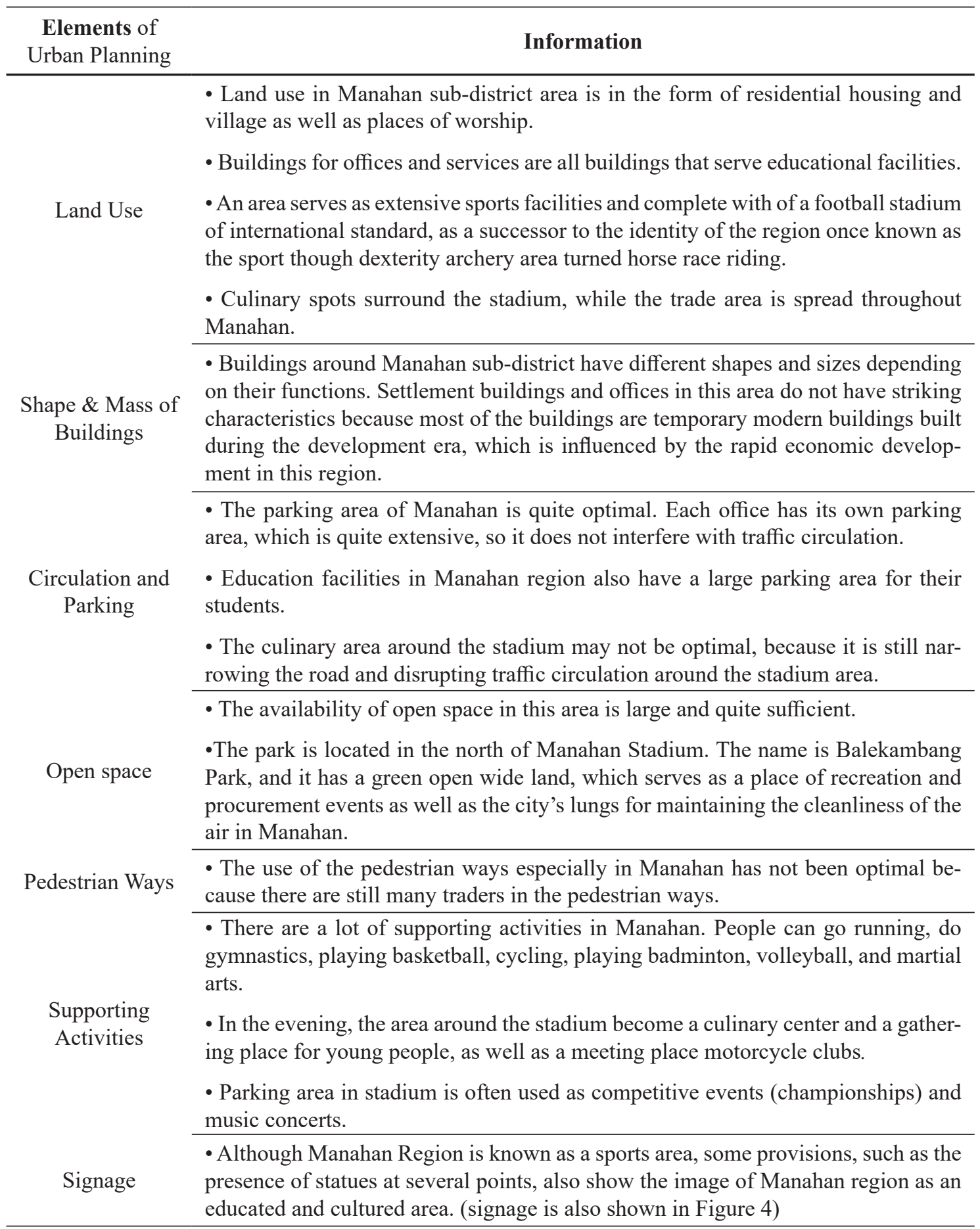

(Source: Author's Analysis, 2017) 


\section{Non-physical Analysis of the Area}

Table 5. Activities in Manahan Sub-District

\begin{tabular}{|c|c|}
\hline $\begin{array}{l}\text { Activity } \\
\text { Analysis }\end{array}$ & Information \\
\hline \multirow{4}{*}{$\begin{array}{l}\text { Activity System } \\
\text { Analysis }\end{array}$} & $\begin{array}{l}\text { - Sports activities can be seen in Manahan region in the area around Manahan } \\
\text { Stadium. }\end{array}$ \\
\hline & - Trade activities are present around Manahan Stadium such as Sunday Morning. \\
\hline & $\begin{array}{l}\text { - Education activities are characterized by the presence of school buildings located in } \\
\text { Manahan, as a facility to support the educational needs of the Manahan community. }\end{array}$ \\
\hline & $\begin{array}{l}\text { - The number of offices and shops in the area around Manahan shows the many } \\
\text { activities of offices and services. }\end{array}$ \\
\hline Social Analysis & $\begin{array}{l}\text { - Over time, the development of Manahan area is growing rapidly. The establishment } \\
\text { of sports center in Manahan provoked the development of other social activities. }\end{array}$ \\
\hline $\begin{array}{l}\text { Economic } \\
\text { Analysis }\end{array}$ & $\begin{array}{l}\text { - The economic activities run by the offices and services around Manahan are based } \\
\text { on the prominence of Manahan as one of the main iconic areas in Solo. Manahan } \\
\text { also provides sports area and wide public space. }\end{array}$ \\
\hline
\end{tabular}

(Source: Author's Analysis, 2017)

\section{Analysis of Image of Cultured and Educated Manahan}

This analysis is based on the analysis of Physical and Non Physical areas that have been discussed above. There have been many changes and developments such as the construction of the Manahan Stadium, the number of offices and houses, and presence of culinary spots in Manahan nowadays. Because of the rapid developments in this area, Manahan have become an iconic area as well as the heart of Solo without losing its historic image as a sports area.

The city of culture idea that was applied to Manahan region based on the theory of Koentjaraningrat (1996) was very suitable. The situation in Manahan shows the culture and education. In 2015, there was a change of signage in front of Manahan Stadium. The masks in front of Manahan stadium as an iconic signage had been changed into a statue of Ir. Soekarno (Figure 6).

The image of the people of Solo who are cultured and educated is also evident during the initial operation of the Manahan Flyover. On the first launching, traffic jam occurred on the flyover. Today, such problem has been under control. This proves that the Solo community is adaptable with new things, and that the people of Solo are educated and cultured. In addition, the flyover also becomes the icon at Manahan for delivering the creativity of youth around Solo especially in decorating the walls underneath with bright and colorful murals. In regard to this, the Surakarta Government have applied strict rules to prevent vandalism.

Figure 6. A change of signage in front of Manahan Stadium

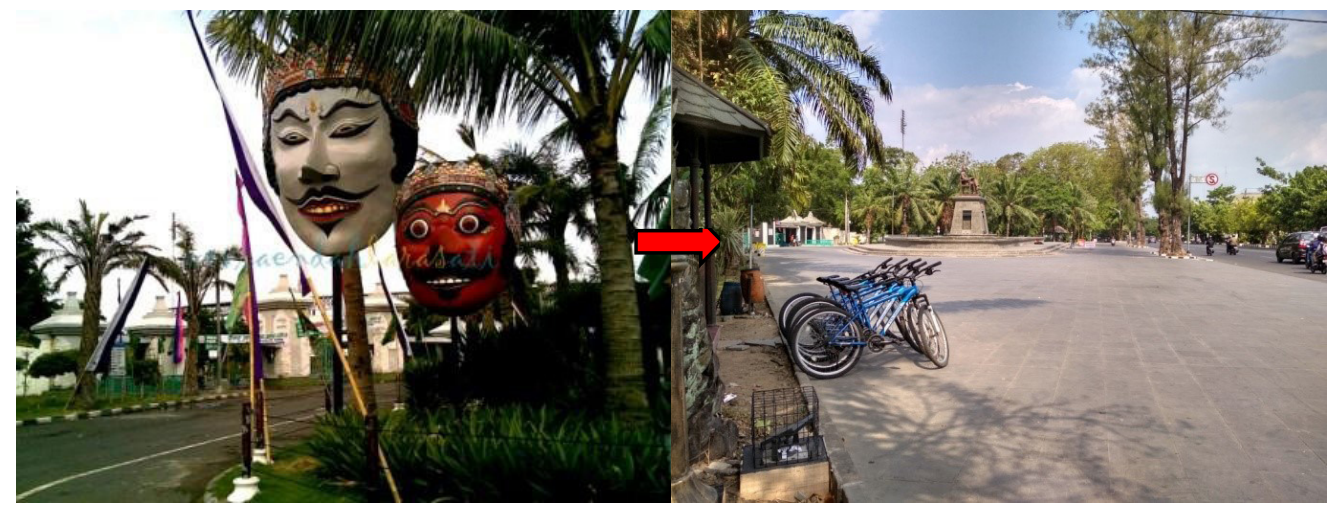




\section{CONCLUSION}

The Manahan area is an iconic area in Solo City, especially in Manahan Village, and has an important role in shaping the city's image as a sports tourism area. Apart from having the image of a sports area, Manahan also has an image as a cultured and educated area. To exhibit an image of a region that is cultured and educated, the Solo government made changes by replacing two traditional masks with a statue of Ir. Soekarno. The aim of shaping the image of the Manahan region is also to achieve aspects of beauty (aesthetics) for the residents and other people as well as the distinctive features/ identities of the Solo city.

Based on the history, Manahan was an area for agility or sports. This tradition continues today with the construction of the Manahan Stadium as a sports area as well as a landmark in the Manahan region. The stadium boosts the economic development, as several offices and services are built around Stadium. Today, the Manahan region is a modern area and public space for communities and others.

The Manahan Flyover, which began operating at the end of 2018, also provides a new color in cultivating a cultured and educational image in the Manahan region. Despite the pros and cons, researchers gave a positive appreciation of the Manahan Flyover design. The design of flyover is made massive without any bridges and given bright colorful paint which reflects the spirit of "millennial" youth. The design under the bridge anticipates the existence of an irregular environment which creates slums. Stadium Manahan is now in a state of renovation to become one of the destinations for sports (FIFA standards) with International standard in 2019; thus must be designed to minimize the slum pockets (related to low maintenance). Now, the traffic at Manahan Flyover has begun to be more organized despite the viral situation in the first time it was operated.

\section{SUGGESTIONS}

In the effort to preserve the Manahan area, several processes are conducted to establish the image of the cultured and educated Manahan region, namely:

- Maintain the preservation and greenness of the environment around the Manahan area, especially in the stadium complex, so that its image is maintained as a landmark of Manahan Village and as a green, clean and healthy public space in the Manahan region.

- Pay more attention to the visitors' parking spot of the culinary area around the Manahan Stadium, so that it is more organized and presentable, and does not disturb the traffic circulation around the stadium.

- Pay more attention to the pedestrian path around the Manahan Stadium to make it more convenient, so that its use for pedestrians can be more optimal.

\section{REFERENCES}

Branch, M.C. (1995). Perencanaan Kota Komprehensif : pengantar \& penjelasan. Yogyakarta: Gadjah Mada University Press.

Iswanto, D. (2006). Pengaruh Elemen- Elemen Pelengkap Jalur Pedestrian Terhadap Kenyamanan Pejalan Kaki (Studi Kasus: Penggal Jalan Pandanaran, Dimulai dari Jalan Randusari Hingga Kawasan Tugu Muda). Jurnal IImiah Perancangan Kota dan Permukiman. 5(1).

Koentjaraningrat. (1996). Pengantar Antropologi. Jakarta: Rineka Cipta.

Lynch, K. (1969). The Image of The City. Cambridge, Massachusetts: MIT Press.

Markus, Z. (1999). Perancangan Kota Secara Terpadu. Yogyakarta: Kanisius.

Rapoport, A. (1977). Human Aspect of Urban Form, Towards a Man-Environment Approach to Urban Form and Design. Oxford: Pergamon Press.

Rapuano, Michael, DR. P. P. Pirone and Brooks E. Wigginton. 1964. Open Space in Urban Design. Ohio: The Cleveland Development Foundation. Published thesis. Architecture Engineering Master's program. Universitas Diponegoro.

Shirvani, H. (1985). Urban Design Process. New York: Van Nostrand Reinhold.

Trancik, R. (1986). Finding Lost Space, Theories of Urban Design. New York: Van Nostrand Reinhold.

Wicaksono, Y.I. (1989). Analisa Kapasitas Parkiryang Optimal dan Penentuan Lay Out Bangunan Parkir yang cocok. Unpublished thesis. Transportation Master's program, Institut Teknologi Bandung. 
Sejarah Manahan di waktu dulu. (n.d). Retrieved from http://www.kelurahanmanahan. wordpress.com/sejarah/, accessed on 2709-2017

Dinas Kependudukan Dan Pencatatan Sipil Kota Surakarta. (2017, February). Profil Perkembangan Kependudukan Kota Surakarta Tahun 2017. Retrieved from http://dispendukcapil.surakarta. go.id/20XIV/images/pdf/PROFIL DKB_201702.pdf accessed on 15-04-2019 